\title{
SYNTHESIS OF THREE NEW BIFUNCTIONAL GLUCOSE- THIOUREA ORGANOCATALYSTS AND THEIR APPLICATION IN ASYMMETRIC MICHAEL ADDITION
}

\author{
SÁNDOR NAGYa, PETRA KOZMAA, PÉTER KISSZÉKELYIa, \\ DÓRA BEZZEGH ${ }^{a}$, PÉTER HUSZTHYa, JÓZSEF KUPAla, ${ }^{a, *}$
}

\begin{abstract}
Three new glucose-based asymmetric bifunctional organocatalysts containing a 6-aminopyridyl or a 6-methylpyridyl or a cinchona unit were synthesized. Asymmetric Michael addition of pentane-2,4-dione to $\beta$-nitrostyrene was catalyzed successfully by these catalysts. In case of the cinchona based glucose-thiourea derivate the $S$ enantiomer of the corresponding Michael adduct was formed with moderate enantiomeric excess in three different solvents.
\end{abstract}

Keywords: organocatalyst, carbohydrates, cinchona alkaloids, Michael addition, asymmetric syntheses

\section{INTRODUCTION}

Chiral catalysts containing both acidic and basic (nucleophilic) structural units are of growing importance in the development of asymmetric synthesis $[1,2]$.

Thiourea derivatives play important roles in catalyst design and modification. Numerous asymmetric reactions, such as aldol, Mannich, Michael, Henry, amination, Biginelli, cyanosilylation and aza-Morita-BaylisHillman reactions, have been accomplished by these catalysts [3]. Recently, bifunctional thiourea derivatives have been recognized as effective organocatalysts for asymmetric Michael addition reactions [4-6]. Therefore, the development of simple and efficient bifunctional thiourea catalysts has great interest. Carbohydrates are easily accessible chiral precursors of asymmetric catalysts [7]. Glucose is very attractive because of its availability and well-defined stereochemistry. Recently, cinchona derived thiourea catalysts have received special attention in the field of organocatalysis [4, 8-10]. The interaction between the catalyst and the reactants can be promoted by the protonated nitrogen of the chiral cinchona skeleton (Figure 1) [6].

\footnotetext{
a Budapest University of Technology and Economics, Department of Organic Chemistry and Technology, 1111, Budapest, Szent Gellért tér 4., Hungary

${ }^{*}$ Corresponding author: jkupai@mail.bme.hu
} 


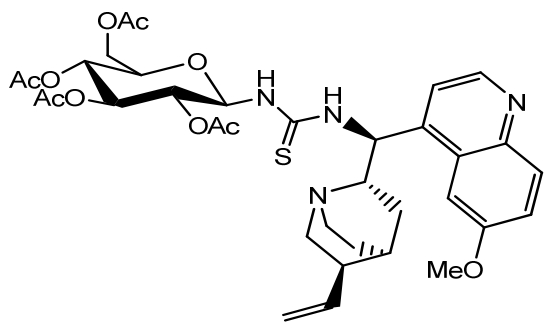

1

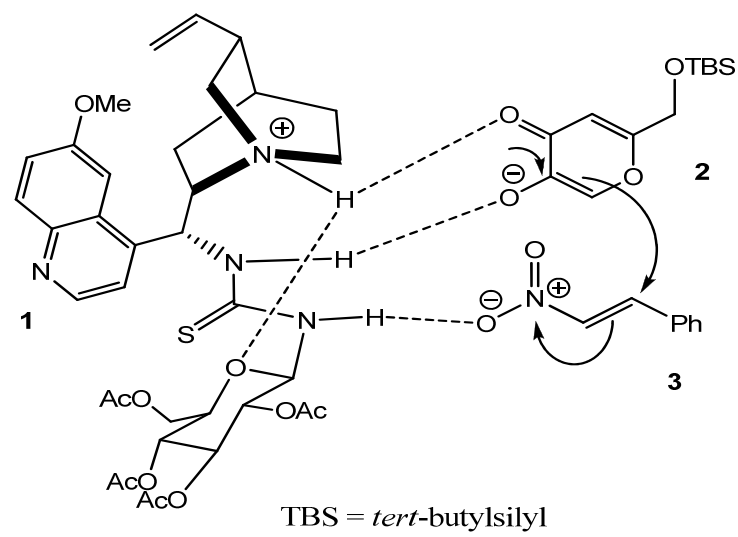

Figure 1. Mechanism of a glucose-based thiourea catalyst (1) promoting Michael addition of 2 enolate to $\beta$-nitrostyrene (3) [6].

The Michael addition reaction is one of the most elegant approaches for the construction of carbon-carbon bonds under mild condition in an atom economic fashion [12].

Inspired by thiourea based organocatalysis, our aim was the synthesis of novel glucose-cinchona hybrids for asymmetric Michael addition reactions. The addition of pentane-2,4-dione to $\beta$-nitrostyrene is important, because the product of this reaction is an intermediate in the synthesis of baclofen, a GABA receptor agonist drug.

\section{RESULTS AND DISCUSSION}

\section{Synthesis}

The common precursor of our new organocatalysts is the tetraacetyl glucose isothiocyanate 4 (Scheme 1), which was synthesized from commercially available D-glucose (5). It was $\mathrm{O}$-acetylated with acetic anhydride in the presence of sodium acetate at $100{ }^{\circ} \mathrm{C}$. The reaction gave pentaacetyl glucose (6) as a 
main product with high yield [13]. The acetobromo glucose (7) was prepared in the reaction of glucose pentaacetate 6 with acetic acid solution of hydrogen bromide (Method $\mathrm{A}$ ) or with phosphorous tribromide in chloroform with catalytic amount of water (Method B). We gained the bromo derivative 7 with higher yield in case of the latter method (69\% instead of $30 \%)$ [14]. Then the glucose isothiocyanate $\mathbf{4}$ was prepared using a reported procedure [15]. Bromo sugar derivative 7 was reacted with potassium thiocyanate in the presence of tetrabutylammonium iodide (TBAl) as phase transfer catalyst at $50{ }^{\circ} \mathrm{C}$ using molecular sieve $(3 \AA)$. This reaction gave the sugar precursor 4 with a medium yield $(63 \%)$.
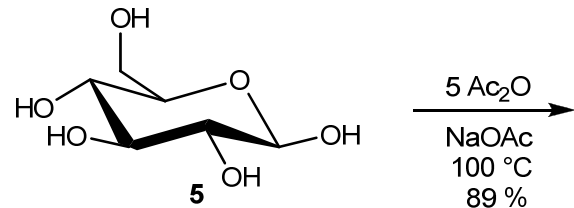

$89 \%$

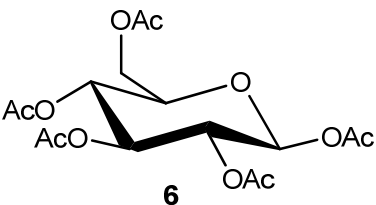
A: $\mathrm{HBr} / \mathrm{HOAC}$
B: 1. $\mathrm{PBr}_{3}$
2. $\mathrm{H}_{2} \mathrm{O}, \mathrm{CHCl}_{3}$
A: $30 \%$
B: $69 \%$

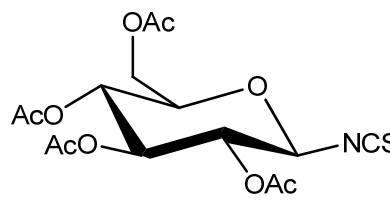

4

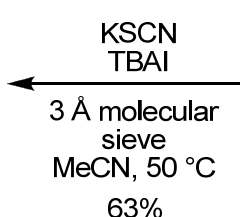

$63 \%$

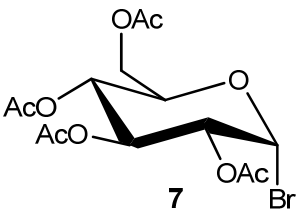

Scheme 1. Synthesis of glucose isothiocyanate derivative 4.

The cinchona skeleton was built up starting from commercially available hydroquinine (8) (Scheme 2). First the hydroxyl group at C9 position of the cinchona was converted into amino group in a one-pot reaction using a reported procedure [8]. In a Mitsunobu reaction applying diisopropyl azodicarboxylate (DIAD) and diphenylphosphoryl azide (DPPA) the corresponding azide was formed [8], which was reduced to amine 9 by a Staudinger reaction using triphenylphosphine in tetrahydrofuran (THF). The demethylation of methoxy derivative 9 was performed using DCM solution of boron tribromide [16] affording cinchona precursor 10 with a high yield (85\%). 


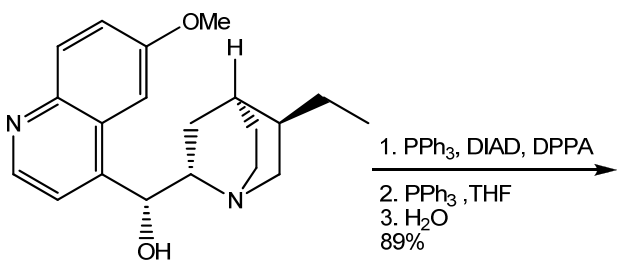

8<smiles>CC[C@H]1CN2CC[C@@H]1C[C@H]2[C@H](N)c1ccnc2ccc(OC)cc12</smiles>

9<smiles>CC[C@H]1CN2CC[C@@H]1C[C@H]2[C@H](N)c1ccnc2ccc(O)cc12</smiles>

10

Scheme 2. Synthesis of the cinchona precursor 10.

In order to prepare bifunctional organocatalysts we needed to react the glucose isocyanate precursor $\mathbf{4}$ with amines bearing a basic skeleton (like quinuclidine or pyridine) forming hydrogen bond donor thiourea derivatives Three new potential enantioselective organocatalysts 11-13 were synthesized in the reaction of the sugar isothiocyanate 4 and three amines containing quinuclidine (10), or pyridine (14 or 15) moieties in acetonitrile at $50^{\circ} \mathrm{C}$ (Scheme 3 ).

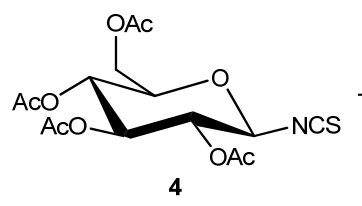

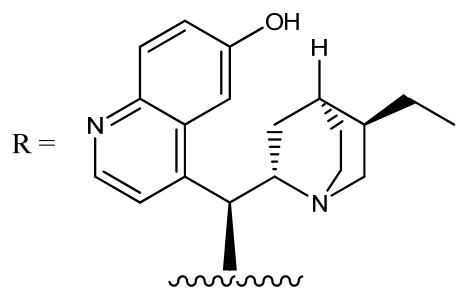

(converting $\mathbf{1 0}$ into 11)

yield: $32 \%$

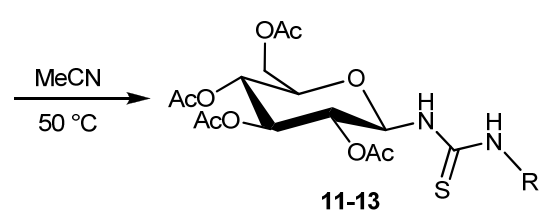<smiles>[Z6]c1cccc(C)n1</smiles><smiles>[Z6]c1cccc(N)n1</smiles>

(converting 14 into 12) (converting 15 into 13) yield: $51 \%$

Scheme 3. Synthesis of new glucose-based bifunctional organocatalysts 11-13. 


\section{Application of the new organocatalysts in asymmetric Michael addition}

In recent studies $[6,17]$ carbohydrate thiourea derivatives showed good enantioselectivities in Michael reactions in acetonitrile and dichloromethane. In addition, according to our unpublished results, cinchona thioureas and squaramides obtain excellent chiral induction in Michael reactions in methyl tert-butyl ether (MTBE). Thus, new glucose-thiourea catalysts 11-13 were used in the Michael addition of pentane-2,4-dione (16) to $\beta$-nitrostyrene (3) (Scheme 4) in the above mentioned three solvents. In case of cinchona catalyst 11 the highest enantiomeric excess with a moderate yield was achieved in MTBE (Table 1). In dichloromethane and acetonitrile only lower yield and enantiomeric excess were obtained. In case of pyridine based catalysts 12 and $\mathbf{1 3}$ only racemic products were isolated, so the successful asymmetric induction needs not only the glucose but the cinchona unit as well.

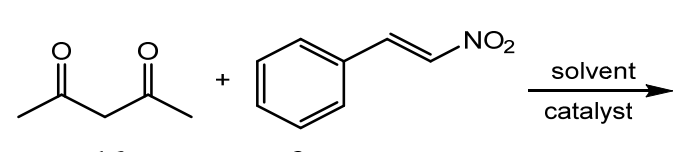

16

3<smiles>CC(=O)C(C(C)=O)C(C[N+](=O)[O-])c1ccccc1</smiles>

17

Scheme 4. Asymmetric Michael addition catalyzed by the new organocatalysts.

Table 1. Results of the test reactions.

*: Determined from optical rotations by comparing to the literature value [18]

\begin{tabular}{|c|c|c|c|c|c|c|c|c|c|}
\hline Catal. & \multicolumn{3}{|c|}{11} & \multicolumn{3}{c|}{$\mathbf{1 2}$} & \multicolumn{3}{|c|}{$\mathbf{1 3}$} \\
\hline$\%(\mathrm{n} / \mathrm{n})$ & 1 & 1 & 1 & 1 & 1 & 1 & 1 & 1 & 1 \\
\hline Solvent & DCM & MTBE & MeCN & DCM & MTBE & MeCN & DCM & MTBE & MeCN \\
\hline Yield & 42 & 40 & 28 & 31 & 32 & 26 & 33 & 37 & 30 \\
\hline ee $(\%,(S))^{*}$ & 58.6 & 64.1 & 36.6 & \multicolumn{3}{|c|}{ racemate } & \multicolumn{3}{c|}{ racemate } \\
\hline
\end{tabular}

Nowadays more and more attention is paid to protect our environment, so catalyst recovery can be a useful tool for reach this goal. Our recent article [19] presents a preliminary study of the potential of the so-called organic solvent nanofiltration (OSN) [20-22] in the purification and recovery of pyridino- and piperidino-crown ether based organocatalysts. According to these results, the sustainable technology of OSN has been proposed for catalyst 11 and solvent recovery based on which we will shortly report a new process for our organocatalysts in asymmetric Michael additions. 


\section{CONCLUSIONS}

Three new enantiopure, glucose-based thiourea organocatalysts (11-13) were synthesized and the cinchona based one (11) was successfully applied in Michael addition of pentane-2,4-dione (16) to $\beta$-nitrostyrene (3) in three different solvents. Using the pyridine based organocatalysts (12 and 13) only racemic products were obtained with lower yields. Presumably the high basicity of the quinuclidine unit is needed for the higher yield, and the cinchona skeleton is also necessary for the successful asymmetric induction.

\section{EXPERIMENTAL SECTION}

\section{General}

Infrared spectra were recorded on a Bruker Alpha-T FT-IR spectrometer. Optical rotations were measured on a Perkin-Elmer 241 polarimeter. NMR spectra were recorded in $\mathrm{CDCl}_{3}$ either on a Bruker DRX-500 Avance spectrometer (at $500 \mathrm{MHz}$ for ${ }^{1} \mathrm{H}$ and at $125 \mathrm{MHz}$ for ${ }^{13} \mathrm{C}$ spectra) or on a Bruker 300 Avance spectrometer (at $300 \mathrm{MHz}$ for ${ }^{1} \mathrm{H}$ and at $75 \mathrm{MHz}$ for ${ }^{13} \mathrm{C}$ spectra) and it is indicated in each individual case. Mass spectra were recorded on CAMAG TLCMS Interface (HPLC pump: Shimadzu LC-20AD Prominence SQ MS: Shimadzu LCMS-2020 MS settings: Detector Voltage: $1.10 \mathrm{kV}, \mathrm{m} / \mathrm{z}$ : 105-1000, Scan speed: $1075 \mathrm{u} / \mathrm{sec}$, DL temperature: $250{ }^{\circ} \mathrm{C}$, Nebulizing Gas Flow: $1.5 \mathrm{~L} / \mathrm{min}$, Drying Gas Flow: $15 \mathrm{~L} / \mathrm{min}$. eluent: acetonitrile: $0.1 \mathrm{v} / \mathrm{v} \%$ formic acid $95: 5,1.500 \mathrm{~mL} / \mathrm{min}$ ). Elemental analyses were performed on a Vario EL III instrument (Elementanalyze Corp., Germany) in the Microanalytical Laboratory of the Department of Organic Chemistry, Institute for Chemistry, L. Eötvös University, Budapest, Hungary. Melting points were taken on a Boetius micro-melting point apparatus and they were uncorrected. Starting materials were purchased from Aldrich Chemical Company unless otherwise noted. Silica gel $60 \mathrm{~F}_{254}$ (Merck) plates were used for TLC. Silica gel 60 (70-230 mesh, Merck) was used for column chromatography. Ratios of solvents for the eluents are given in volumes $(\mathrm{mL} / \mathrm{mL})$. Evaporations were carried out under reduced pressure unless otherwise stated.

\section{$(2 S, 3 R, 4 S, 5 R, 6 R)-(+)-2-($ Acetoxymethyl)-6- isothiocyanatotetrahydro-2 $\mathrm{H}$-pyran-3,4,5-triyl triacetate (4)}

Potassium thiocyanate $(3.35 \mathrm{~g}, 30 \mathrm{mmol})$ and tetrabutyl ammonium iodide ( $3.2 \mathrm{~g}, 8.6 \mathrm{mmol}$ ) were dissolved in anhydrous acetonitrile. $3 \AA$ molecular sieve $(12.74 \mathrm{~g})$ was added and the mixture was stirred for $2.5 \mathrm{~h}$ at room temperature. A solution of acetobromo glucose (7) $(3.54 \mathrm{~g}, 8.6 \mathrm{mmol})$ in acetonitrile $(3.5 \mathrm{~mL})$ was added to the reaction mixture and it was stirred for $7 \mathrm{~h}$ at $50{ }^{\circ} \mathrm{C}$. The reaction was monitored by $\mathrm{TLC}\left(\mathrm{SiO}_{2} \mathrm{TLC}\right.$; hexane:ethyl acetate $=1: 1$, 
$R_{f}=0.40$ ). The mixture was filtered and the solid material was washed with acetonitrile. The filtrate was evaporated. The residue was dissolved in dichloromethane $(300 \mathrm{~mL})$, and it was shaken with water $(3 \times 300 \mathrm{~mL})$. The combined organic phase was dried over anhydrous $\mathrm{MgSO}_{4}$ and evaporated. The crude product was purified by column chromatography on silica gel using hexane:ethyl acetate (1:1) mixture as an eluent to give white crystals $(2.11 \mathrm{~g}$, $63 \%)$.

M.p.: $112-114{ }^{\circ} \mathrm{C}$ (lit. $\left.\mathrm{mp}: 112{ }^{\circ} \mathrm{C}[15]\right) ;[\alpha]_{\mathrm{D}}^{25}=+5.5\left(c 1.00 \mathrm{CHCl}_{3}\right)$ (lit.: $\left.[\alpha]_{\mathrm{D}}^{25}=+5.0\left(\mathrm{c} 1.00 \mathrm{CHCl}_{3}\right)[15]\right)$. The obtained product had the same spectroscopic data than those of reported [15].

\section{$(2 S, 3 R, 4 S, 5 R, 6 R)-(+)-6$-(Acetoxymethyl)tetrahydro-2H-pyran- 2,3,4,5-tetrayl tetraacetate (6)}

A mixture of anhydrous sodium acetate $(16 \mathrm{~g}, 195 \mathrm{mmol})$ and anhydrous D-glucose (5) $(20.0 \mathrm{~g}, 111 \mathrm{mmol})$ in acetic anhydride $(100 \mathrm{ml}, 1.06$ mol) was heated at $100{ }^{\circ} \mathrm{C}$ for $2 \mathrm{~h}$. The reaction was monitored by TLC $\left(\mathrm{SiO}_{2}\right.$ TLC; methanol:toluene $\left.=1: 4, R_{f}=0.55\right)$. After the reaction was completed the mixture was poured into cold water and the white precipitate was filtered off and washed with water. The crude product was recrystallized from methanolwater to give white crystals $(38.56 \mathrm{~g}, 89 \%)$.

M.p.: $130-133^{\circ} \mathrm{C}$ (lit. mp: $131-132^{\circ} \mathrm{C}$, methanol-water [23]); $[\alpha]_{\mathrm{D}}^{25}=+3.7$ (c $1.00 \mathrm{CHCl}_{3}$ ) (lit.: $[\alpha]_{\mathrm{D}}^{25}=+4.0\left(c 1.00 \mathrm{CHCl}_{3}\right)$ [23]). The obtained product had the same spectroscopic data than those of reported [23].

\section{$(2 S, 3 R, 4 S, 5 R, 6 R)-(+)-2-($ Acetoxymethyl)-6-bromotetrahydro-2H- pyran-3,4,5-triyl triacetate (7)}

Method A: A solution of hydrogen bromide in acetic acid $(35 \mathrm{~mL}, 35 \mathrm{w}$ $\%$ ) was added dropwise to pentaacetyl glucose (6) $(7.93 \mathrm{~g}, 20 \mathrm{mmol})$ at $0{ }^{\circ} \mathrm{C}$. The mixture was stirred at this temperature for $2 \mathrm{~h}$ and then at room temperature overnight. The reaction was monitored by $\mathrm{TLC}\left(\mathrm{SiO}_{2} \mathrm{TLC}\right.$; hexane:ethyl acetate $=1: 1, R_{f}=0.79$ ). After the reaction was completed the mixture was poured into cold water and the precipitated white crystals were filtered off. The latter crude product was dissolved in dichloromethane $(100 \mathrm{~mL})$, and washed with water $(100 \mathrm{~mL})$. The organic phase was separated, dried over anhydrous $\mathrm{MgSO}_{4}$ and filtered. The filtrate was evaporated. Hexane $(20 \mathrm{~mL})$ was added to the residue and the precipitated white crystal was filtered off $(2.47 \mathrm{~g}, 30 \%)$.

M.p.: $78-80^{\circ} \mathrm{C}$ (lit. $\mathrm{mp}: 77-79^{\circ} \mathrm{C}$, ethyl acetate-petroleum ether [24]); $[\alpha]_{\mathrm{D}}^{25}=+181\left(c 1.00 \mathrm{CHCl}_{3}\right)\left(\right.$ lit: $\left.[\alpha]_{\mathrm{D}}^{25}=+182.0\left(c 1.00 \mathrm{CHCl}_{3}\right)[24]\right)$.

The obtained product had the same spectroscopic data than those of reported [24]. 
Method B: Phosphorous tribromide $(3.9 \mathrm{~mL}, 40 \mathrm{mmol})$ in dichloromethane $(20 \mathrm{~mL})$ was added dropwise to a solution of pentaacetyl glucose (6) in dichloromethane $(80 \mathrm{~mL})$. The reaction mixture was stirred for $30 \mathrm{~min}$, then water $(1.4 \mathrm{~mL})$ was added and stirred for $2 \mathrm{~h}$. The reaction was monitored by $\mathrm{TLC}\left(\mathrm{SiO}_{2} \mathrm{TLC}\right.$; hexane:ethyl acetate $\left.=1: 1, \mathrm{R}_{\mathrm{f}}=0.62\right)$. After the reaction was completed saturated sodium bicarbonate solution $(110 \mathrm{~mL})$ was added to the mixture and stirred for $20 \mathrm{~min}$. The mixture was diluted with water $(200 \mathrm{~mL})$ and extracted with dichloromethane $(3 \times 200 \mathrm{~mL})$. The combined organic phase was dried over anhydrous $\mathrm{MgSO}_{4}$, filtered and evaporated. Hexane $(20 \mathrm{~mL})$ was added to the residue and the precipitated white solid was filtered off (5.67 g, 69\%).

M.p.: $78-80^{\circ} \mathrm{C}$ (lit. mp: $77-79{ }^{\circ} \mathrm{C}$ (ethyl acetate-petroleum ether) [24]); $[\alpha]_{\mathrm{D}}^{25}=+181\left(c 1.00 \mathrm{CHCl}_{3}\right)$ (lit.: $[\alpha]_{\mathrm{D}}^{25}=+182.0\left(\right.$ c $\left.1.00 \mathrm{CHCl}_{3}\right)$ [24]). The obtained product had the same spectroscopic data than those of reported [24].

\section{$(1 S, 2 S, 4 S, 5 R)-(+)-5-E t h y l q u i n u c l i d i n-2-y l)(6-m e t h o x y q u i n o l i n e-4-$ yl)methaneamine (9)}

Hydroquinine $(8,1.5 \mathrm{~g}, 4.6 \mathrm{mmol})$ and triphenylphosphine $(1.47 \mathrm{~g}, 5.6$ $\mathrm{mmol})$ were dissolved in dry THF $(16 \mathrm{~mL})$ under nitrogen at $0{ }^{\circ} \mathrm{C}$. Diisopropyl azodicarboxylate (DIAD) $(1.2 \mathrm{~mL}, 5.6 \mathrm{mmol})$ was added and the mixture was stirred at $0{ }^{\circ} \mathrm{C}$ for $2 \mathrm{~h}$. A solution of diphenylphosphoryl azide (DPPA) $(1.2 \mathrm{~mL}$, $5.6 \mathrm{mmol})$ in THF $(5 \mathrm{~mL})$ was added dropwise to this solution. The mixture was stirred at room temperature for $16 \mathrm{~h}$, and then at $45{ }^{\circ} \mathrm{C}$ for $30 \mathrm{~min}$. Triphenylphosphine $(1.47 \mathrm{~g}, 5.6 \mathrm{mmol})$ was added and the mixture was stirred at room temperature for $2 \mathrm{~h}$, until the gas evolution stopped. In order to form amine, water $(1.5 \mathrm{~mL})$ was added and then this mixture was stirred for $2 \mathrm{~h}$. After evaporation of THF the aqueous residue was shaken with the mixture of DCM $(20 \mathrm{~mL})$ and $2 \mathrm{M} \mathrm{HCl}(20 \mathrm{~mL})$. The aqueous phase was extracted with DCM $(2 \times 20 \mathrm{~mL})$, and the $\mathrm{pH}$ was adjusted to 10 with $10 \%$ aqueous $\mathrm{NaOH}$ solution. Then it was extracted with DCM $(3 \times 15 \mathrm{~mL})$. The combined organic phase was dried over anhydrous $\mathrm{MgSO}_{4}$, and the solvent was evaporated. The crude product was dissolved in dry diethyl ether $(20 \mathrm{~mL})$ and $2 \mathrm{M} \mathrm{HCl}$ solution in diethyl ether $(10 \mathrm{~mL})$ was added. The precipitated solid was filtered off and washed with diethyl ether $(5 \mathrm{~mL})$ (trihydrochloric salt formed, $1.8 \mathrm{~g}$ ) to give the crude product as pale yellow crystals. M.p.: $200^{\circ} \mathrm{C}$ (decomposes) (lit. mp: $214-215^{\circ} \mathrm{C}$ (decomposes) (ethyl acetate-methanol) [25]).

The trihydrochloric salt was dissolved in water $(20 \mathrm{~mL})$ and the $\mathrm{pH}$ was adjusted to 10 with $10 \%$ aqueous $\mathrm{NaOH}$ solution to form the free base. This aqueous solution was extracted with DCM $(3 \times 20 \mathrm{~mL})$. The combined organic phase was dried over anhydrous $\mathrm{MgSO}_{4}$ and evaporated to give cinchona amine $9(1.31 \mathrm{~g}, 89 \%)$ as a pale yellow oil. 
$[\alpha]_{\mathrm{D}}^{25}=+63.6\left(c 0.97 \mathrm{CHCl}_{3}\right)$ (lit.: $\left.[\alpha]_{\mathrm{D}}^{25}=+71.8\left(c 0.97 \mathrm{CHCl}_{3}\right)[8]\right)$. The obtained product had the same spectroscopic data than those of reported [8].

\section{4-(-)-((1S)-Amino((2S,4S,5R)-5-ethylquinuclidin-2- yl)methyl)quinoline-6-ol (10)}

Methoxamine $(9,0.96 \mathrm{~g}, 2.95 \mathrm{mmol})$ was dissolved in dry DCM $(96 \mathrm{~mL})$ under nitrogen. Boron tribromide (12 mL, $1 \mathrm{M} \mathrm{DCM}$ solution, $12 \mathrm{mmol}$ ) was added dropwise to it and the mixture was stirred for $4 \mathrm{~h}$ at $40{ }^{\circ} \mathrm{C}$. The mixture was cooled to room temperature, then filtered, and the solvent was evaporated. The crude product was purified by preparative thin layer chromatography on silica gel using trimethylamine ( $45 \mathrm{~V} / \mathrm{V} \%$ in water): methanol: acetonitrile: (0.1:1:1) mixture as an eluent to give pale brown crystals $(0.78 \mathrm{~g}, 85 \%)$.

M.p.: $135^{\circ} \mathrm{C}$ (decomposes) $[\alpha]_{\mathrm{D}}^{25}=-10.2^{\circ}(c 0.6 \mathrm{MeOH})$ The obtained product had the same spectroscopic data than those of reported [16].

\section{General procedure for the formation of glucose-based thiourea organocatalysts (11-13)}

Amine derivative (10 or $\mathbf{1 4}$ or 15, regarding the amounts see below for each components) was added (Scheme 3 ) to a solution of isothiocyanate 4 (regarding the amounts see below for each components) in acetonitrile $(70 \mathrm{~mL}$ ) under argon. The mixture was stirred for $7 \mathrm{~h}$ at $50^{\circ} \mathrm{C}$. The reaction was monitored by $\mathrm{TLC}\left(\mathrm{SiO}_{2} \mathrm{TLC}\right.$; methanol:toluene:triethylamine $\left.=1: 3: 0.1\right)$. After the reaction was completed the solvent was evaporated. The residue was dissolved in a mixture of DCM $(80 \mathrm{~mL})$ and water $(80 \mathrm{~mL})$. The organic phase was separated and dried over over anhydrous $\mathrm{MgSO}_{4}$, filtered and evaporated. The crude product was purified as described below for each compound to result in new thiourea derivatives.

$(2 R, 3 R, 4 S, 5 R, 6 R)-(+)-2-($ Acetoxymethyl)-6-(3-((S)-((2S,4S, 8R)-8ethylquinuclidin-2-yl)(6-hydroxyquinolin-4-yl)methyl) thioureido)tetrahydro-2H-pyran-3,4,5-triyl triacetate (11)

The glucose-based thiourea organocatalyst 11 was prepared as described above in the General procedure starting from cinchona amine 10 (75.8 $\mathrm{mg}, 0.24 \mathrm{mmol})$ and isothiocyanate $4(94.8 \mathrm{mg}, 0.24 \mathrm{mmol})$. The crude product was purified by preparative thin layer chromatography on silica gel using methanol:toluene:triethylamine (1:3:0.1) mixture as an eluent to give 11 (55 mg, 32\%) as white crystals.

$\mathrm{R}_{\mathrm{f}}: 0.45\left(\mathrm{SiO}_{2}\right.$ TLC, methanol:toluene:triethylamine $\left.=1: 3: 0.1\right) ;$ m.p.: $169-173{ }^{\circ} \mathrm{C} ;[\alpha]_{\mathrm{D}}^{25}=+4.0\left(c 1.00 \mathrm{CHCl}_{3}\right)$; IR (KBr) $v_{\max } 3415,2960,2918$, 2850, 1741, 1621, 1540, 1490, 1472, 1464, 1399, 1362, 1262, 1214, 1196, 1083, $1030,907,855,803,777,730,720,692,661,645,581,495 \mathrm{~cm}^{-1} ;{ }^{1} \mathrm{H}$ NMR 
$\left(500 \mathrm{MHz}, \mathrm{CDCl}_{3}\right) \delta(\mathrm{ppm})$ 0.76-0.81 (m, 3H), 0.81-0.88 (m, 1H), 1.12-1.21 $(\mathrm{m}, 2 \mathrm{H}), 1.29-1.34(\mathrm{~m}, 5 \mathrm{H}), 1.98-2.06(\mathrm{~m}, 12 \mathrm{H}), 2.34-2.36(\mathrm{~m}, 1 \mathrm{H}), 2.64-$ $2.68(\mathrm{~m}, 1 \mathrm{H}),, 2.97-3.04(\mathrm{~m}, 3 \mathrm{H}), 3.79-3.83(\mathrm{~m}, 2 \mathrm{H}), 4.23-4.27(\mathrm{~m}, 1 \mathrm{H})$, 5.00-5.10 (m, 2H), 5.27-5.33 (m, 2H), 5.64-5.75 (m, 1H), 5.77 (br. s, $1 \mathrm{H})$, 7.13-7.26 (m, 2H), 7.39-7.42 (m, 1H), $8.03(\mathrm{~d}, 1 \mathrm{H}), 8.72(\mathrm{~d}, 1 \mathrm{H}), 9.97$ (br. s, $1 \mathrm{H}), 11.39$ (d, 1H); ${ }^{13} \mathrm{C} \mathrm{NMR}\left(125 \mathrm{MHz}, \mathrm{CDCl}_{3}\right) \delta$ (ppm) 12.10, 20.60, 20.70, 20.90, 21.20, 25.30, 26.10, 27.60, 28.20, 37.40, 41.30, 50.60, 57.80, 61.70, $62.00,68.20,68.70,70.40,73.50,82.90,105.10,123.20,123.30,129.40$, $131.40,143.70,146.50,146.80,156.50,169.40,169.80,170.00,170.90$, 182.40. MS: $700.28(\mathrm{M}+1)^{+}$. Anal. Calcd. for $\mathrm{C}_{34} \mathrm{H}_{44} \mathrm{~N}_{4} \mathrm{O}_{10} \mathrm{~S}$ : C 58.27, H 6.33, N 7.99, S 4.57 \%, found: C 58.24, H 6.39, N 7.98, S $4.55 \%$.

\section{$(2 R, 3 R, 4 S, 5 R, 6 R)-(+)-2-($ Acetoxymethyl)-6-(3-(6-methylpyridin-2- yl)thioureido)tetrahydro-2H-pyran-3,4,5-triyl triacetate (12)}

Glucose-based thiourea organocatalyst 12 was prepared as described above in the General procedure starting from 2-amino-6-methylpyridine (14, $71 \mathrm{mg}, 0.66 \mathrm{mmol})$ and isothiocyanate $4(100 \mathrm{mg}, 0.26 \mathrm{mmol})$. The crude product was purified by preparative thin layer chromatography on silica gel using hexane:ethyl acetate (1:1) mixture as an eluent to give 12 (102 mg, $80 \%)$ as a white oil.

$\mathrm{R}_{\mathrm{f}}: 0.34\left(\mathrm{SiO}_{2} \mathrm{TLC}\right.$, hexane:ethyl acetate $\left.=1: 1\right) ;[\alpha]_{\mathrm{D}}^{25}=+0.2(c 1.00$ $\left.\mathrm{CHCl}_{3}\right)$; IR (KBr) $v_{\max } 3230,3195,3126,304,2948,1757,1732,1618,1557$, 1539, 1451, 1367, 1296, 1245, 1222, 1210, 1177, 1161, 1129, 1117, 1073, 1055, 1037, 938, 913, 903, 845, 780, 748, 716, 667, 653, 628, 597, 572, 509, 473, $450 \mathrm{~cm}^{-1} ;{ }^{1} \mathrm{H}$ NMR $\left(500 \mathrm{MHz}, \mathrm{CDCl}_{3}\right) \delta(\mathrm{ppm}) 1.95(\mathrm{~s}, 3 \mathrm{H}), 2.00(\mathrm{~s}, 3 \mathrm{H})$, $2.03(\mathrm{~s}, 3 \mathrm{H}), 2.06(\mathrm{~s}, 3 \mathrm{H}), 2.50(\mathrm{~s}, 3 \mathrm{H}), 3.89-3.94(\mathrm{~m}, 1 \mathrm{H}), 4.06-4.08(\mathrm{~m}, 1 \mathrm{H}$,$) ,$ 4.11-4.15 (m, 1H), 5.13-5.16 (m, 1H), 5.19-5.23 (m, 1H), 5.35-5.39 (m, 1H) 5.86-5.92 (m, 1H), $6.67(\mathrm{~d}, 1 \mathrm{H}), 6.82(\mathrm{~d}, 1 \mathrm{H}), 7.52(\mathrm{t}, 1 \mathrm{H}), 9.39$ (br. $\mathrm{s}, 1 \mathrm{H})$, 12.74 (d, $1 \mathrm{H}) ;{ }^{13} \mathrm{C}$ NMR $\left(75.5 \mathrm{MHz}, \mathrm{CDCl}_{3}\right) \delta$ (ppm) 20.68, 20.71, 20.87, $21.13,23.66,61.94,68.43,68.61,70.30,73.62,82.80,109.11,118.34$, 139.20, 152.38, 156.14, 169.74, 169.74, 170.07, 170.80, 182.74. MS: 495.15 $(\mathrm{M}+1)^{+}$. Anal. Calcd. for $\mathrm{C}_{21} \mathrm{H}_{27} \mathrm{~N}_{3} \mathrm{O}_{9} \mathrm{~S}$ : C 50.70, H 5.47, N 8.45, S $6.44 \%$, found: C 50.67, H 5.49, N 8.44, S $6.44 \%$.

\section{$(2 R, 3 R, 4 S, 5 R, 6 R)-(-)-2-($ Acetoxymethyl)-6-(3-(6-aminopyridin-2- yl)thioureido)tetrahydro-2H-pyran-3,4,5-triyl triacetate (13)}

Glucose-based thiourea organocatalyst 13 was prepared as described above in the General procedure starting from 2,6-diaminopyridine (15, $131 \mathrm{mg}$, $0.51 \mathrm{mmol})$ and isothiocyanate $4(200 \mathrm{mg}, 0.51 \mathrm{mmol})$. The crude product was purified by preparative thin layer chromatography on silica gel using hexane:ethyl acetate (1:1) mixture as an eluent to give $13(131 \mathrm{mg}, 51)$ as pale yellow oil. 
$\mathrm{R}_{\mathrm{f}}: 0.66\left(\mathrm{SiO}_{2} \mathrm{TLC}\right.$, hexane:ethyl acetate $\left.=1: 1\right) ;[\alpha]_{\mathrm{D}}^{25}=-18.0(c 1.00$ $\left.\mathrm{CHCl}_{3}\right)$; IR (KBr) $v_{\max } 3480,3379,3220,3139,2965,1754,1631,1609,1584$, $1531,1455,1368,1262,1229,1165,1095,1042,921,799,725,703,661$, 600, 475, $406 \mathrm{~cm}^{-1} ;{ }^{1} \mathrm{H}$ NMR (500 MHz, CDCl$) \delta(\mathrm{ppm}) 1.92(\mathrm{~s}, 3 \mathrm{H}), 1.94(\mathrm{~s}$, $3 \mathrm{H}), 1.96(\mathrm{~s}, 3 \mathrm{H}), 1.98(\mathrm{~s}, 3 \mathrm{H}), 3.96-3.99(\mathrm{~m}, 1 \mathrm{H}), 4.02-4.04(\mathrm{~m}, 1 \mathrm{H}), 4.18$ $4.21(\mathrm{~m}, 1 \mathrm{H}), 4.99-5.03(\mathrm{~m}, 1 \mathrm{H}), 5.38-5.43(\mathrm{~m}, 2 \mathrm{H}), 5.85-5.88(\mathrm{~m}, 1 \mathrm{H}), 6.10$ (d, 1H), 6.19 (br. s, 2H), 6.24 (d, 1H), 7.35 (t, 1H), 10.52 (br. s, 1H), 12.49 (d, $1 \mathrm{H}) ;{ }^{13} \mathrm{C}$ NMR $\left(75.5 \mathrm{MHz}, \mathrm{CDCl}_{3}\right) \delta(\mathrm{ppm}) 20.26,20.33,20.39,20.53,61.82$, 68.12, 70.47, 72.16, 72.59, 81.53, 98.77, 101.74, 139.76, 151.83, 156.89, 169.38, 169.45, 169.52, 170.01, 181.48. MS: $498.14(\mathrm{M}+1)^{+}$. Anal. Calcd. for $\mathrm{C}_{20} \mathrm{H}_{26} \mathrm{~N}_{4} \mathrm{O}_{9} \mathrm{~S}$ : C 48.19, H 5.26, N 11.24, S 6.43 \%, found: C 48.17, H 5.31, N 11.22 , S $6.42 \%$.

\section{General procedure for asymmetric Michael reaction}

Organocatalysts $11-13(0.03 \mathrm{mmol})$ and $\beta$-nitrostyrene $(3,894.9 \mathrm{mg}$, $6.0 \mathrm{mmol}$ ) were added to a solution of pentane-2,4-dione $(16,307 \mu \mathrm{L}, 300.4 \mathrm{mg}$, $3.0 \mathrm{mmol}$ ) in different solvents (see Table 1). The reaction mixture was stirred at room temperature while monitored by $\mathrm{TLC}\left(\mathrm{SiO}_{2} \mathrm{TLC}\right.$; acetone:chloroform $=$ $1: 100, R_{f}=0.63$ ). After the reaction was completed (about a day) the solvent was removed. The crude product was purified by preparative thin layer chromatography on silica gel using acetone:chloroform (1:100) mixture as an eluent to give Michael adduct 17 as white crystals (yields, e.e values can be seen in Table 1.).

M.p.: $123-126{ }^{\circ} \mathrm{C}$ (lit. mp: $124-126^{\circ} \mathrm{C}$ [19]). The obtained product had the same spectroscopic data than those of reported [19].

\section{ACKNOWLEDGMENTS}

The financial support of the Hungarian Scientific Research Fund/ National Research, Development and Innovation Office, Hungary (OTKA/ NKFIH Nos. K 112289 and PD 108462) is gratefully acknowledged.

\section{REFERENCES}

1. M. Christmann, Stefan Bräse, Asymmetric Synthesis - The Essentials, 2007, $2^{\text {nd }}$ Edition, chapter 1.

2. S.B. Tsogoeva, M.J. Hateley, D.A. Yalalov, K. Meindl, C. Weckbecker, K. Huthmacher, Bioorganic and Medicinal Chemistry, 2005, 13, 5680.

3. M.S. Taylor, E.N. Jacobsen, Angewandte Chemie International Edition, 2006, 45, 1520. 
4. S.J. Connon, Chemical Communications, 2008, 2499.

5. Y. Takemoto, Chemical and Pharmaceutical Bulletin, 2010, 58, 593.

6. B.V.S. Reddy, S.M. Reddy, M. Swain, S. Dudem, S.V. Kalivendi, C.S. Reddy, Royal Society of Chemistry Advances, 2014, 4, 9107.

7. M. Irmak, A. Groschner, M. M. K. Boysen, Chemical Communications, 2007, 177.

8. B. Vakulya, S. Varga, A. Csámpai, T. Soós, Organic Letters, 2005, 7, 1967.

9. B. Vakulya, S. Varga, T. Soós, Journal of Organic Chemistry, 2008, 73, 3475.

10. S. Bota, I. Neda, L. Silaghi-Dumitrescu, Studia UBB Chemia, 2011, 56, 279.

11. C. Curti, G. Rassu, V. Zambrano, L. Pinna, G. Pelosi, A. Sartori, L. Battistini, F. Zanardi, G. Casiragi, Angewandte Chemie International Edition, 2012, 51, 6200.

12. P. Perlmutter, Conjugate addition reactions in organic synthesis, Pergamon: Oxford, UK, 1992.

13. Zhang S.; Moussodia, R.O.; Sun, H.J.; Leowanawat, P.; Muncan, A.; Nusbaum, C.D.; Chelling, K.M.; Heiney, P.A.; Klein, M.L.; André, S.; Roy, R.; Gabius, H.J.; Percec, V. Angewandte Chemie International Edition, 2014, 53, 10899.

14. S.C. Timmons, D.L. Jakeman, Organic Letters, 2007, 9, 1227.

15. M.J. Camarasa, P. Fernández-Resa, M.T. García-López,F.G. De Las Heras, P.P. Méndez- Castrillón, A. San Felix, Synthesis, 1984, 509.

16. C. Cassani, R. Martin-Rapun, E. Arceo, F. Bravo, P. Melchiorre, Nature Protocols, 2013, 8, 325.

17. B.V.S. Reddy, S.M. Reddy, M. Swain, Royal Society of Chemistry Advances, 2013, 3, 930.

18. D.A. Evans, S. Mito, D. Seidel, Journal of the Americal Chemical Society, 2007, 129, 11583.

19. J. Kupai, P. Kisszékelyi, E. Rojik, G. Dargó, L. Hegedűs, D. Bezzegh, P. Maszler, L. Szabó, T. Németh, Gy. T. Balogh, P. Huszthy, Arkivoc, 2016, 130-151.

20. J.F. Kim, G. Szekely, M. Schaepertoens, I.B. Valtcheva, M.F. Jimenez-Solomon, A. G. Livingston, ACS Sustainable Chemistry \& Engineering, 2014, 2, 2371.

21. G. Szekely, M.F. Jimenez-Solomon, P. Marchetti, J.F. Kim, A.G. Livingston, Green Chemistry, 2014, 16, 4440.

22. M. Schaepertoens, C. Didaskalou, J.F. Kim, A.G. Livingston, G. Szekely, Journal of Membrane Science, 2016, 514, 646.

23. D. Wahler, O. Boujard, F. Lefevre, J.-L. Reymond, Tetrahedron, 2004, 60, 703.

24. L.A. Yu-Ya, J.M. Chalker, B.G. Davis, Journal of the American Chemical Society, 2010, 132, 16805.

25. S.H. McCooey, S.J. Connon, Organic Letters, 2007, 4, 599. 